\author{
Henrik Åström Elmersjö \\ Umeå University \\ Robert Thorp \\ Uppsala University
}

DOI: http://dx.doi.org/10.5617/adno.7780

\title{
The Cold War, Historical Culture and History Education: Swedish Teachers' Entangled Narratives of History and Memory
}

\begin{abstract}
This article presents an analysis of seven Swedish lower secondary school teachers' personal experiences of the Cold War period, told in life story interviews which also related to their profession as history teachers. The aim is to analyze how personal experiences of history and personal memories may affect how history is approached by teachers and to discuss what relevance that may have for history education. Applying theories of historical culture and collective memory, we argue that the interviewed teachers display a collectivized historical experience imbued with cultural contingency, both entangled with - and at the same time detached from - personal memory. The reproduction of historical culture and collective memory seems detached from personal experience and instead, related to cultural narratives. The study finds that the teachers' personal experiences are strongly affected by and filtered through the culturally contingent narratives of the historical period in which the teachers have lived their lives. Furthermore, the interviewed teachers did not address the reconstructive and disciplinary aspects of history that may arguably be an essential aspect of history education in Sweden and most Western countries.
\end{abstract}

Keywords: Collective Memory, History Education, Cold War, History Teachers, Historical Culture

\section{Kalla kriget, historiekultur och historieundervisning: Svenska lärares sammanflätning av historiska berättelser och minnen}

\begin{abstract}
Sammandrag
I den här artikeln analyseras sju svenska högstadielärares personliga upplevelser från kalla kriget, berättade i livsberättelse-intervjuer som också relaterade till deras yrke som lärare. Livsberättelse-intervjuerna skapade förutsättningar för en analys av hur lärarnas personliga erfarenheter av historia och deras personliga minnen kan påverka hur de närmar sig historien, vilket också öppnar för en diskussion om vilken relevans deras minnen har för deras historieundervisning. Genom en analys med historiekultur och kollektivt minne som teoretiska verktyg, menar vi att de intervjuade lärarna uppvisade
\end{abstract}


tecken på en kollektiviserad historisk erfarenhet genomsyrad av kulturell kontingens sammanlänkad med - och samtidigt avskild från - personliga minnen. Reproduktionen av historiekulturen och ett kollektivt minne förefaller ha varit avskild från personliga erfarenheter och istället relaterad till kollektiva berättelser. Studien visar även att lärarnas personliga erfarenheter och minnen är starkt påverkade av, och filtrerade genom, de kulturellt betingade berättelser som beskriver den period då lärarna har levt. I intervjuerna saknades emellertid tecken på en insikt i hur lärarnas minnen påverkats av kulturellt betingade berättelser om kalla kriget. Lärarna utelämnar även diskussioner om de rekonstruktiva och disciplinära aspekterna av historia, som kan sägas vara en viktig del av historieundervisning i Sverige och i större delen av västvärlden.

Nyckelord: kollektivt minne, historieundervisning, kalla kriget, historielärare, historiekultur

\section{Introduction}

History teachers are not merely professionals implementing an official task regulated by curricula or syllabi. They are also individuals with personal memories and experiences of the past and history that go well beyond what is stipulated in the history curriculum. As individuals they are members of historical cultures that constitute what history they encounter and what parts of the past they will perceive as meaningful and relevant (Persson, 2017; Thorp, 2019). Furthermore, history teachers are individuals with personal experiences and memories that shape and affect how they approach history. Following this line of argumentation, we claim that this could pose a challenge to history education since what is being taught in history classes relates to aspects of history that go beyond the classroom or history textbooks. History education, in this view, is a culturally imbued practice where social, societal and personal aspects (implicit and explicit alike) play a prominent role in how history teachers perceive the history they encounter (cf. Porat, 2004; Persson \& Thorp, 2017; Zanazanian \& Moisan, 2012).

What does all this mean for history education or, more specifically, for the teaching of contemporary history where the teacher has personal memories of the events discussed in the history classroom? History teachers can, arguably be pivotal to the dissemination of historical knowledge in any society, and therefore the main instrument in the diffusion of mainstream official historical culture. For instance, in an article on communist nostalgia in Romania, Pohrib (2016) points to the process of intergenerational transmission of memory becoming entangled with memory politics in contemporary society. This stresses the importance of researching how historical culture influences personal memory, and how the entanglement of history and memory makes room for culturized, collectivized and politicized personal memories, as well as historical culture reflecting those memories. Wineburg et al. (2007) have come to similar conclusions in the United States. These findings in earlier research show the need to get a deeper understanding of how teachers' personal views on history and personal memories 
as well as their epistemic attitudes towards history affect how they approach teaching the subject and view their own meaning making in relation to it.

In this article we set out to analyze how Swedish history teachers - born no later than 1970, and thus with personal memories of the Cold War - tell the story of a past they are tasked to teach. Applying the concepts of entangled memory, historical culture and the historiographic gaze we intend to discuss how intertwined memories, official knowledge, and historical culture might influence history teachers' views on lived history and - by extension - history education. More specifically, the research questions we intend to answer are: (i) How do history teachers with personal memories of the Cold War spontaneously relate their memories to historical events, official knowledge and historical culture? (ii) Do the teachers spontaneously distance themselves from historical culture, engaging with an historiographical gaze and express contextual awareness? We further intend to discuss how a focus on teachers' personal experiences of history and personal memories in relation to their professional practice may provide a new focus in research on history education. A fundamental theoretical assumption here is that history and the teaching thereof always will be characterized by complexity, contingency and entanglement.

It has previously been shown how history teachers' personal experiences directly influence their teaching and - in the teachers' own conception - make it easier to teach due to the fact that they are teaching their own experience (Thorp, 2017; Zanazanian, 2009). In this article we wish to look to how teachers' personal experiences are intertwined through the mediation of historical culture, and howwhile they are personal and reflect personal views - these experiences might be more connected to impersonal, culturally contingent official knowledge (Apple, 1993) and cultural memory (Assmann, 1992) than to actual personal experience. We also want to analyze if and how teachers' historiographic gaze, or historical cultural self-awareness, influence how they talk about their experiences of growing up during the Cold War period and their history teaching. The focus of this article will be on the influence of an abstract historical culture, on seemingly tangible personal, ideological, and historical positions.

Memory and history have often been argued to be deeply intertwined. As Halbwachs (1992) suggested already in the first part of the twentieth century, this entanglement is rooted in the collectiveness of memory; in the notion that memories are shared and therefore defined collectively (see also Becker, 2005; Cubitt, 2007, p. 118-174; Climo \& Catell, 2002). This means that individuals who remember are not recalling past reality in isolation. To remember something is to share it with others and a sense of continuity among a group's members is often associated with remembering (Pakier \& Stråth, 2010). When personal memories are repeated they are collectivized and connected to events remembered by others, and to societal historical culture. This is perhaps logical; in order to narrate personal memory, a common reference point is needed: "When the historical event $\mathrm{x}$ happened, I was doing $\mathrm{y}$, and you were doing $\mathrm{z}$.” From the perspective of 
collective memory, it more or less follows that historical events and personal memories will become increasingly inter-connected the more people talk about them. Correspondingly, two different personal memories may also be interconnected, in their common relation to the same historical event. In this sense, the $\mathrm{y}$ and $\mathrm{z}$, in the example above can be understood as two events happening to two different people, perhaps in different parts of the world, seemingly unrelated to each other, but still entangled in the memory of the persons involved, due to their relation to the historical - that is, culturally significant - event x (cf. Cubitt, 2007; Schrager, 1983).

In her study of Australians' relationship to the past and history, Clark commented that "[t]he national narrative, often presented in school texts and curriculums with conventional periodisations and themes [...] was understood by participants [her respondents] in the context of personal anecdotes and memories shared in their focus groups" (Clark, 2016, p. 40). Thus, to feel connected with history is to situate it in personal memories and experiences. Similar results have been shown in American and Canadian studies where respondents bridged their personal experiences and memories with larger, collective, and national themes, but without repeating grand narratives of the national past (Rosenzweig $\&$ Thelen, 1998; Conrad et al., 2013). These results indicate that individual memory will be influenced by historical culture and therefore entangled with history. Even if there is no such thing as a completely individual memory (Halbwachs 1992) since all memories are shaped by social norms regarding what is relevant to remember, it does not have to be entangled with events that are considered historical in the sense that they are part of official knowledge about the past. This is also one of the reasons why collective memory is hard to distinguish from history, but there is still a need to clarify the differences between people remembering things from their own life, and what they learn about the past as part of the official knowledge regarded as History. If there is no distinction between the terms, they cannot be entangled, because they would be the same thing.

A common way of distinguishing history from memory is to focus on the critical reconstruction inherent in history. While memory is deeply associated with personal experiences, albeit in a collective sense, history, on the other hand, rests on the critical inquiry of historical sources. Through a rigid methodological process, the historian thus seeks to disentangle herself from her personal beliefs and experiences and instead create an historical account that solely rests on the information provided to her by historical sources (Lévesque 2008; Parkes 2011). In a sense you could say that the ideal here is to view history as disentangled from personal beliefs, experiences and memories. This methodological process can, however, also be seen as entangled if we take into account that all historical inquiries take place within a historical culture.

Historical culture is a term sometimes used to describe the set of narratives embraced and communicated as cultural memory among a group of people. However, and differing from cultural memory, a historical culture is both the 
process and the structure of making sense of the past within a specific societal context. It covers both how history is communicated and which history is communicated (Rüsen, 2002; 2007). The concept of historical culture is thus important in order to understand how history, much like memory, is contingent on the cultural context that it is intended to make sense of (see e.g. Elmersjö, 2015). It is, however, important to clarify a distinction between history and collective memory:

Collective memory is not history, though it is sometimes made from similar material. It is a collective phenonmenon but it only manifests itself in the actions and statements of individuals. It can take hold of historically and socially remote events but it often privileges the interests of the contemporary. (Kansteiner, 2002, p. 180)

Still, the distinction between memory and history has been argued to be difficult to uphold, as there "is no such thing as 'pure history' devoid of the characteristics of memory” (Seixas, 2018, p. 73; see also Hartog, 2015, p. 122-123; Feindt et al., 2014, p. 41). While historical culture then places constraints on what can be perceived as historically meaningful and relevant, it is also what enables individuals to come into contact with history in a variety of contexts. Thus, historical culture should be understood as a dynamic notion that is constantly being re-enacted, reproduced, renegotiated and reinterpreted, depending on cultural needs (Aronsson, 2004; Karlsson, 2014: Sjöberg, 2011; Elmersjö, 2016). A key aspect in this sense is how individuals approach the historical cultures that they partake in: do they unreflectively confirm and re-enact these historical cultures or do they acknowledge them and position themselves in relation to them? In order to do the latter, it has been argued that individuals need a specific awareness of how history is always situated in cultural contexts and thus contingent on these (Rüsen, 2012; Thorp, 2016). A key aspect here is how individuals, among them history teachers, approach history cognitively.

Parkes (2011) coined the term "the historiographic gaze" to illustrate how individuals may approach history in epistemically different ways. According to Parkes, an individual practicing a historiographic gaze will realize and appreciate how history is always constructed in specific contexts and contingent to these contexts, thus acknowledging the influence of historical culture. This means that the individual will never take historical narratives at face value, but rather assess under what conditions they were constructed and for what possible aims. Furthermore, this individual will express self-awareness concerning his or her own historical and contextual situatedness and carefully assess how this affects how he or she approaches history: "historiography as a metahistorical discourse [...] extends the gaze of the historian to everything, even themselves, revealing the historical specificity of all historical forms of knowledge and practice" (Parkes, 2011, p. 102). If we relate this to historical culture, the historiographic gaze can be understood as what enables the individual to epistemically recognize the significance of historical culture in order to be able to transcend the specific 
historical cultures he or she finds him- or herself in. This kind of awareness thus enables the individual to regard all history as a form of cultural enterprise that is contingent to this fact, instead of treating historical narratives as if they were objective, factual and impervious to change. Thus, an individual possessing a historiographic gaze will always engage with the cultural contingency and situatedness of historical accounts and her own approaches to them.

\section{Sweden and the Cold War}

We have deliberately chosen to define the Cold War in terms of a particular time period (1945-1991), instead of focusing on more political, cultural, ideological or historical aspects of this rather vague notion (cf. Furrer \& Gautschi, 2016). This choice was made in order to embrace all possible approaches to the Cold War. However, in order to situate the results presented below to an international audience, we want to give a brief and general view of how the Cold War is regarded in Sweden and in Swedish history education, based on earlier research (see e.g. Holmén, 2006; Dalsjö, 2006; Thorp, 2016). This view should not be considered as comprehensive or complete, but rather an attempt at painting a general picture of the Cold War in Swedish historical culture. On a societal or political level, Sweden has a long tradition of conflicts with Russia dating back to the late $17^{\text {th }}$ and early $18^{\text {th }}$ centuries. From a Swedish point of view this culminated in 1809 when Sweden lost its eastern parts (i.e. Finland) to Russia. While Swedish international politics were oriented towards the European continent in general, and Germany in particular, during the $19^{\text {th }}$ century, there was a marked shift after World War II when Sweden orientated itself towards the USA and the Englishspeaking world. This was to a great extent inspired by distrust towards the USSR. While Sweden was officially neutral, there were covert co-operation with the USA and NATO during the 1950's and 1960's since the Swedish government considered the USSR to be its "natural enemy” (Dalsjö, 2006). In 1981 the Soviet submarine U 137 was found stranded in the archipelago of the southern Swedish coast and this inspired a heated political and medial debate about Soviet espionage and military threats to Sweden that came to shape and further strengthen the public opinion of the USSR as a threat to Swedish national security during the 1980's.

This view of the USSR is corroborated by Swedish history textbooks. Holmén (2006) shows how Swedish textbooks continually describe the USSR in a negative manner and this is a trend that escalates after the fall of the USSR in 1991. These results have also been corroborated by further research on Swedish history textbooks (see Thorp, 2015). In general terms, the Cold War is perceived as a conflict between a communist and oppressive East, led by the USSR and a democratic and free West, led by the USA, and the image presented of the Cold War in Swedish history textbooks can be described as a series of Western reactions to Soviet aggressions. While motives and reasons are generally given to 
explain the acts of the Western powers and the USA, this is rarely the case with the USSR. It is instead implicitly and explicitly stated that the USSR acts for ideological reasons and that it strives to spread communism in the world (Thorp, 2015). This very basic structure for making sense of the Cold War conflict can also be found in the national Swedish history syllabus for lower secondary school where it is stated that the Cold War was a conflict that ended with the collapse of the USSR (Skolverket, 2011), thus implicitly linking the conflict to the existence of the USSR.

Taken together, this shows what could be called a deeply rooted perception of Russia and the USSR as the Other in Swedish historical culture generally and particularly so concerning the Cold War period. This also has reverberations for Swedish history education since the historical culture concerning the Cold War in Sweden is so manifest and normalized (Thorp, 2015; Persson \& Thorp, 2017, Thorp, 2017).

\section{Method}

Since we wanted to study history teachers' relationships to historical culture and memory and how these relationships may be affected by epistemic approaches to history, we chose to perform what may be called life-story interviews with seven active Swedish lower secondary school history teachers. The aim of a life-story interview is to allow analyses of respondents' ways of making sense in a broad sense of the term (Linde, 1993). Using as few prompts as possible the researcher should try to make the respondent talk about and explain things in his or her own way, often at a more personal level.

The cue the teachers were given at the beginning of the interview was to tell us about their life from as far back as they could remember and how their life experiences have shaped them as history teachers. We asked the teachers to bring up what they thought was important, to start their narratives in their childhood and to try to present their narrative in a chronological order. There were three reasons for these instructions: (i) we wanted them to tell us of their personal experiences in order to make them talk about memories of life long ago, (ii) we asked them to bring up what they thought was important to elicit data telling us something about what was perceived as historically relevant from a more historical-cultural perspective, and (iii) we asked them to try to narrate their stories chronologically in order to bring the reproductive aspects of history and memories to the fore. While the teachers' narratives were what directed the interviews, we still had prepared questions on how they remembered their personal backgrounds, different political and historical issues, and questions related to their choice of profession and experiences of teaching, should they not talk about these topics in their interviews. We did not specifically ask the teachers to reflect on the cultural or reconstructive aspects of history highlighted above, 
since (a) we argue that this is implicit in the cue they were given, that is how their personal experiences shaped them as history teachers, and (b) that would negate our interest in seeing if they would spontaneously discuss history in terms of contingency and culture. All questions were of an open-ended character and were directed at making the respondents tell us their story in their own words. All interviews were conducted in the fall of 2014 at the teachers' respective schools at a time of their own choice. All the interviews were audio recorded and transcribed shortly afterwards. It is these transcriptions that have been used in the analyses.

In order to get respondents that would have some experience of growing up during the Cold War period we chose to contact teachers who were born no later than 1970. Lower secondary schools in the central parts of Sweden were contacted and the teachers were informed of the objective of the study before they consented to participate. We interviewed the teachers twice. In the first interview we asked them about their views on history education and asked them to interpret a number of textbook quotations relating to the Cold War. In the second interview, which is the one we have analyzed here, we asked the teachers to relate their childhood memories of growing up to their profession as history teachers. The teachers we interviewed came from mixed backgrounds and were of mixed gender. All of the interviewed teachers had at least ten years' experience of working as lower secondary school history teachers. Below is some short information about the respondents; their gender, how old they were when interviewed, for how long they had been teachers, their background, and their self-proclaimed teaching agenda. The interviewed teachers' names have been substituted for a code ( $F$ for female and $\mathrm{M}$ for Male and numbered 1 to 4 ) in order to protect the identities of the respondents.

- F1 is a female teacher born in 1959. She has worked as a teacher since the mid 1980's and she has worked at the same school her entire professional career. She comes from a working class background with a strong socialdemocratic orientation. She describes her teaching agenda as directed towards helping her students make sense of the world through studying history.

- F2 is a female teacher born in 1955. She started working as a teacher later in her life and has experiences of working in factories and driving buses. She comes from a middle class background with a conservative political orientation. She professes no particular teaching agenda, but expresses distance towards textbooks and other teaching material that she often finds to be too left-wing and critical of the Western world.

- F3 is a female teacher born in 1964. She started working as a teacher in her 30 's and has experience of working as an office clerk. She comes from a middle class background with vague political orientations. Her teaching 
agenda is directed towards making her students interested in history and to make connections between events and periods.

- F4 is a female teacher born in 1965. She started working as a teacher later in her life and has long experience of living abroad. She comes from an upper middle class background with a strong right wing orientation. She describes her teaching agenda as directed towards making her students empathize with historical persons and she focuses on teaching the history of ideas in class.

- M1 is a male teacher born in 1970. He worked in the manufacturing industry until his mid-thirties and then chose to become a teacher. He comes from a working class background with a strong social-democratic orientation. He describes his teaching agenda as directed towards trying to accommodate students and making them interested in the subject.

- M2 is a male teacher born 1964. He worked as a bus driver and shop assistant before becoming a teacher in his thirties. He comes from a working class background with a social-democratic orientation. His teaching agenda is directed towards making students think for themselves and he views the history subject as the social studies of the past.

- M3 is a male teacher born in 1964. He worked as a caretaker in a mental asylum until his late twenties and then decided to become a teacher. He has a working class background with a strong social-democratic orientation. His teaching agenda is directed towards making personal connections to history and he claims to use his own experiences a lot when he teaches. Students should study history to learn about life.

When analyzing the teacher interviews, we began by reading the interview transcriptions extensively and then we focused on the two aspects that are central to this article. Firstly, we studied how the teachers' narratives indicated how their personal experiences are intertwined or entangled with the historical culture of Swedish official knowledge, by focusing on the questions: "What personal recollections and reflections did the teachers express, indicative of a personal relationship to the past?", and "What impersonal culturally contingent official knowledge did the teachers express?" We highlighted statements where the respondents themselves connected their personal memories to historical events which they did not personally experience. Secondly, in order to analyze how the teachers expressed a historiographic gaze or historical-cultural self-awareness, we studied whether and how the teachers expressed self-distance in relation to their narratives of personal and culturally embedded aspects of history, and to which extent they expressed an awareness of how history is situated and culturally and contextually contingent. Here we particularly looked for statements where the respondents contemplated their own situatedness in history and culture or when they spoke about their memories and historical events in terms of cultural, or temporal contingency. 


\section{Results}

In presenting the results we have categorized statements into three topics, two of which most of the interviews revolved around, and the third stemming from our research questions. Most of the interviews revolved around the teachers' own educational experience, general views of the Cold War and the master narrative of "othering the East". These topics are covered in the first two sections below. In the last section we analyze the few statements where the respondents seemed to situate their view of both personal events and historical events in terms of cultural contingency.

\section{Educational experiences and general views of the Cold War}

Interestingly enough, none of the teachers interviewed had any recollection of any extensive education on the Cold War during their own educations. In fact, most of them stated that they could not remember any mention of the Cold War during their history classes in secondary school. When asked if they remember being taught about the Cold War, the teachers responded:

I don’t have any exact memories, but I guess there must have been some... (F1).

I think so, a little bit. But actually you usually stop after the Second World War (M1).

I remember the Second World War [...] I don’t think we got any further (F3).

I think it was a classic case of we only made it to the Second World War (M3).

However, some of the teachers did remember getting taught about subjects related to the Cold War, but as part of social studies, not history. Since the Cold War was contemporaneous to the respondents' schooling, it does make sense that it was part of social studies, but that also seems to have influenced the interviewed teachers' take on the Cold War as something perhaps less historical.

Even when recalling their studies in history at university or teacher college there was not much about the Cold War that was remembered. However, in the case of higher education the interviewed teachers seemed more convinced having read about it, even though they could not remember anything specifically:

Well, when I talk about international politics, maybe I get those mixed up. [...] There was one course that I thought was very, very interesting and I think they called that one international... (F1).

It was a lot of women's history [...] and language history, but... nothing specific on the Cold War, but there was something about it in the literature. But it was mentioned... (M1). 
Well there was some teaching on the Cold War. I remember one lecture [...] because he [the lecturer] presented a different view of the Vietnam War, where he sort of justified the American intervention (F2).

It almost seems as if what the teachers knew about the Cold War was from their own teaching, and their own lives, and not from educational experience. It was not really history, when they studied history. It was life. However, whether or not the teachers remember correctly is beyond the scope of this article.

All teachers recalled the Cold War as a bipolar experience in their private lives. The alleged intrinsic bipolarity of the Cold War could of course be debated. It is probably more accurate to describe the bipolar experience as a culturally supported way of perceiving the Cold War which also lends itself as a teaching tool; a way of dichotomizing the world in order to more easily understand it. One of the teachers also described the problem of teaching the Cold War in terms of difficulties in relating a lot of subject matter from a long time period to a common theme:

The Cold War is among the hardest subjects to teach. [...] To find the common theme from 1945 to 1989 is damn hard. For me, regarding the Cold War, you could mix in the Soviet Union and the US of course, but also the FNL-movement, the Swedish progressive movement, the Vietnam movement in the US, Kampuchea, South Africa, the whole de-colonization. And to get all that into one theme is not easy (M3) ${ }^{1}$.

This statement points to a common problem of history teaching; making sure that a long period of time, disparate and straggly, is neatly described as an era, with one common theme. The bipolarity of the Cold War period could easily be seen as such a theme. However, this bipolarity was not at all described in terms of a teaching tool when the respondents spoke about their own lives, it was rather mentioned in terms of a lived experience of the world. The respondents had clearly experienced the world through this lens of the culturally recognized official knowledge of the Cold War. The historical-cultural contingency of this conception did not seem to be recognized at all, since none of the teachers mentioned anything to that effect.

The neutrality in the teaching of the Cold War was mostly regarded as being neutral within the dichotomy, presenting a fair and just depiction of the two systems. The teachers stressed the importance of recognizing that perceiving the world in a particular way always renders a particular way of understanding history. This insight was, however, never extended to a critical analysis of the bipolar experience and none of the teachers questioned the dichotomy itself. This can probably be seen as part of official knowledge, that is the common-sense assumption about the bipolarity of the Cold War (see, e.g. Apple, 1993; Thorp, 2017).

\footnotetext{
${ }^{1}$ The FNL movement was a Swedish popular movement that mobilized support for the South Vietnamese National Liberation Front (known by its French acronym "FNL”).
} 
When asked about their lives within the timeframe of the Cold War, the interviewed teachers tended to recollect very few actual events. However, they still related their narrative to certain fixed points in one of the more common culturally standardized grand narratives of the Cold War in Sweden. This is perhaps not surprising since that was the task at hand, i.e. to describe growing up during the Cold War era and how that may have affected them as history teachers. However, the memories were quite often connected to a feeling of immediate danger, often related to nuclear weapons and also to nuclear power. Some of the teachers explicitly stated that their own experience in one way or another influenced the way they teach the Cold War, mostly by making use of their personal memories and experiences when telling the students about how it was to live in Sweden during this period (e.g. F1; F4; M2).

All of the teachers explicitly related their narratives to the Chernobyl disaster in 1986 in some way, and in structuring their narratives they consistently linked this to the referendum on nuclear power held in Sweden in 1980. This fact, that the teachers related their memories of the Cold War to a disaster at a nuclear power plant and to a domestic referendum on the issue of nuclear power could probably be related to two issues. First of all, it could indicate that the imminent threat of nuclear war is associated to the threat of nuclear technology in general. Secondly, it could also indicate a cultural conception of the East as a place where a disaster of the magnitude of Chernobyl could happen, as well as the sense of the Soviet government trying to cover up the consequences of the disaster. Only two of the teachers also mentioned the accident at Three Mile Island near Harrisburg in 1979, which - even though less severe - was more closely related to the Swedish referendum on nuclear power in 1980. Thus, this choice of mentioning the referendum in the same context as something that happened six years later (and therefore had nothing to do with the referendum in question) could be perceived as a more or less implicit othering of the East. This choice of ordering the narrative might show how these events, although unrelated, are made to fit into the culturally dominant grand narrative of the Cold War.

\section{Othering the East}

All of the respondents expressed some kind of anxiety or distress towards the East when growing up. They all recalled news stories and a feeling of being threatened by the Soviet Union. In some cases our respondents exemplified this with recollections of the Russian submarine U 137 (S-363) that ran aground on the $27^{\text {th }}$ of October 1981 on the south coast of Sweden (often referred to as "Whiskey on the rocks").

Well I remember watching the news when things happened. They talked a lot on the news about the Warsaw-pact and NATO and things that happened. [...] There was a lot about how different nuclear war heads had been moved, and animated images of movements. [...] Perhaps I never saw it as a threat, [...] but then, when I was 12, it was this business with the submarine that ran aground [...] (M1). 
You were afraid of the Warsaw-pact and all that [...] You were very surprised, of course, when a Russian captain showed up from a submarine right there in Blekinge (F2).

It is hard to convey to students today that we really were afraid [of the East]. And now I haven’t even mentioned the submarines (M3).

These memories were also coupled with recollections of trips made to Eastern Europe during the Cold War, where the immediate impressions were conveyed as a sense of threat, sadness, and gloom.

\begin{abstract}
You were brought up with the threat from Russia. [...] And you knew the Russians dominated Eastern Europe, so when you go there, it is a confirmation of what you already knew. [...] A lot of controls, they wanted to know where you were going, who you were going to meet [...]. They wanted to search your clothing, your shoes, your socks. [...] There was no joy [...]. Of course they had joy in their lives, but not when they were looking towards the West, dreaming (M2).
\end{abstract}

This quotation strongly indicates an entanglement of personal and cultural memory. M2 recalls a trip to Eastern Europe, but he is also invoking images from popular culture and/or the news, picturing Eastern-Europeans "looking towards the West, dreaming." He has experienced the reality of Eastern Europe, but he is also fitting his personal memories to the dominant cultural narrative. He further contends that the experience of the East was a "confirmation of what you already knew." Still, he does not really explain how he knew this. None of the teachers really remembered being taught anything about the Cold War. Instead they point to news, (American) popular culture, for example Bond-movies (M3), the movie Hair (F3) and pop music (all teachers), parents, and neighbors, or "the kitchen table," as M1, puts it. M2 also mentioned that his travels to the East during the Cold War was a useful tool in his own teaching, suggesting that his own memories corroborate other depictions of the East, in textbooks for example: "It is an asset when teaching, because you can tell them how it really was" (M2).

As was shown above, the major Swedish cultural conception of the time can be identified as anti-Soviet, at least politically and military. The teachers in this study were also - generally - able to recall personal experiences to that effect. However, there was also an ambiguity regarding where the conception of the "nice United States" - "the good guys" - came from: "I don't know if it was conveyed through school, or if it was something you heard around you. It was the general opinion" (F3). This "general opinion" can be argued to be a typical indication of a grand narrative outlining what can be called tacit official knowledge (Linde, 2000). None of the interviewed teachers reflected in any way on the cultural contingency of this official knowledge. On the contrary, visiting the East instead seems to have confirmed what they already knew.

One teacher tried to explain why he was taught so little about the Cold War, even at university level: "the left-wing bias, that might have influenced that you actually didn't teach the Cold War. [...]. Because, within the Cold War [as a 
teaching subject] there is a critique of communism" (M2). This points to a common Western conception of the Cold War; that it is unteachable without a criticism of communism. This view is shared by several respondents, where the notion that "more liberalism" equals "more democracy" (F4) is coupled with a teleological view of history as leading us towards liberal democracy. Interestingly, this was also evident among the teachers who identified themselves as politically left-leaning: "The East was like..., even though I will never vote for anything other than the left, it seemed dangerous in some way" (M3). Taken together, this shows the dominance of the master narrative of the Cold War in past and present Swedish historical culture: the Soviet Union was and is perceived as "the Other." However, some of the teachers also recognized an unbalanced view of the USSR in Swedish society, and compared what they considered the actual threat from the USSR during the Cold War to the threat of contemporary Russia: "I would think that you consider Russia more of a threat today. I can't remember that we considered Russia, or the USSR, as a threat then" (F2). On the other hand, this could also be seen as a way of making memories part of an ideological identity in order to make the point that Russia still is a threat, maybe even more so today, come across. In an earlier part of the same interview, the teacher stated that "you were afraid of the Warsaw-pact and all that," suggesting a persisting view of the USSR or Russia as a threat; it is merely a matter of degree.

An interesting, and somewhat different aspect of taking sides in the Cold War relates to sports. Two of the teachers had explicit memories of cheering for the USSR in sports, because Soviet (or Eastern European) athletes were perceived as less driven by money, instead they were regarded as "ordinary people" with "exceptional talent" (M1). This is a take on the Cold War that differs from most of the statements about East and West, as there seems to be a mutuality between what was perceived as something to relate to; the talent and training, as opposed to the money: "We always cheered for the Soviets in hockey. [...] There was a respect for the disciplined training" (F4).

\section{Realizing the entanglement of history and personal memory?}

The conceptualization of the West as something inherently good and the East as something bad (within the framework of the Cold War) was not explicitly related to the consumption of mass culture by our respondents. Still, all the teachers spontaneously related to American mass culture (e.g. music and movies) in the interviews while none related to any Russian or Eastern counterpart, thus indicating a generally westernized world view. This was not perceived as political, but rather as the way things were. When asked why she went to West-Berlin and not East-Berlin, on a trip during the 1980s, F3 responded: "It was not political, it was just easier." In this view, the alienation and renunciation of Eastern Europe is not politicized, instead it is made into common-sense, and the Western perspective of the Cold War, is made - not a political stance - but a consequence of pragmatism, from the perspective of the individual. Of course, these factors 
interact; by evoking a Westernized version of cultural memory, and taking in a Western historical culture, these teachers were also more at ease in the West, not really understanding the East.

This is interesting since the teacher seems to depoliticize the Cold War and make choices connected to it cultural and pragmatic. The clearly western stance is not acknowledged, at least not consistently, and when it is made explicit it is perceived "not political." When asked about their teaching about the subject, our respondents seem to explain the Cold War in terms of geopolitical struggles. The tensions between the West and the East during the Cold War is not made sense of in allegories connected to contemporary anti-liberal ideologies. Instead it is almost always explained in allegories connected to Putin's Russia; to geopolitical ambitions and the small state, i.e. Sweden, that is the neighbor of a big state, i.e. Russia. This is key to understanding the "othering” of Russia in Swedish historical culture. This is not exclusive to the Cold War, but is of great importance in Swedish historical culture and has been for centuries. It also continues today, as is evident in the obvious "explanatory" need for teaching the Cold War in order for students to understand contemporary Russia; Russia is - and has been for a long time - considered a threat, and "the Other," in Swedish collective memory (see e.g., Elmersjö, 2011; Holmén, 2006; Persson, 2019).

M3 also went to West Berlin in 1989, before the Berlin Wall came down, and then he went back in 1990, also visiting the Eastern part of the by then unified city:

We stayed for one night in East Berlin, and even though it was an open city by then you could see the huge differences. It was horrible to see. To go through the east side and see how poor people were. The cars they had. [...] And nowadays you can't see any difference at all [...]. This whole Eastern-Western conflict is a fascinating parenthesis in history (M3).

By relating the experience of walking through the eastern part of a unified Berlin to how it looks today, the differences between the West and the East during the Cold War is emphasized. At the same time, the conflict is dated by referring to it as "a parenthesis in history," and the description of how the East was transformed from something poor to something like the West is a vivid image of a "liberation" of the East. This reinforces the impression that the Western world is considered the norm and the Eastern experience was perceived as a kind of historical abnormality.

Another teacher identified this kind of entanglement of mass culture and official knowledge with his own personal memories, but not really related to the Cold War. While discussing the nuclear power referendum of 1980, the Swedish Prime Minister during large parts of the 1970s and 1980s, Olof Palme, came up: 
Yes, I remember Palme, when he strutted around... The camera always swept around the lectern with his feet and..., well... I remember him as a character [karaktär persona/role]. But I liked Palme (M1).

This statement is telling in that the teacher stopped himself halfway through a sentence and seemed to realize that what he remembered was not really a personal memory, but a recollection of how the Prime Minister had been portrayed, entangled with some personal recollection and imbued with public opinions on Palme. Given that the Prime Minister might have been negatively portrayed in some news media, and that the collective memories about him are very ambiguous in making him out to be both a bully and a savior, the teacher seemed to feel that his recollection of Palme had been "distorted" by a cultural image of him. This is also the only time any of the respondents seemed, for a moment, to realize the effect historical culture might have on personal memories; the effect of collectivized memory. ${ }^{2}$

Another example of the same kind of cultural phenomena turning up in the interviews is one of the female teachers "remembering" the assassination of Kennedy, although she was actually too young to remember:

Eh... Well I think I can’t have remembered Kennedy, the assassination of Kennedy, but I must have had it told..., but he died on my mother's birthday. So that's my earliest memory. [...] My mother said that he was a very special person. That she experienced it like that. [...] He was so young and nice... But, this could have influenced my own image of Kennedy... actually. [...] So I can't really say. But anyway, I remember this. But I must have remembered that she told me this (F2).

There does not seem to be the same recognition of an influence from a collectivized memory in this quotation, but still, there is an acknowledgement regarding early memories; that they are influenced by what you learn later, and by the people around you. Neither of these quotations can be seen as epiphanies regarding the contingency of perspective, and the entanglement of memory. Rather, they are related to specific events and not generalized by the respondents. However, that only makes them more interesting, since while the respondents seem to realize something about memory and its connection to narrative and history, they still do not seem to regard this realization as something that is fundamental for how they remember life during the Cold War in general. Neither of these two respondents make any more spontaneous comments regarding how memory can be influenced by history or culture. And the realization of the entanglement of memory do not seem to have any implications for their further narrative in the interviews.

\footnotetext{
${ }^{2}$ This sort of need for collectivizing the personal memories of historical events that one has been part of, is also present in the vivid literature on the collectivization of the terrorist attacks of September 11 2001, an event that seemed to transform from event to history in real-time (Hartog, 2015, p. 104; see also e.g., Hirst et al., 2015; Zeltner, 2010).
} 


\section{Conclusions}

The anti-Russian sentiment of Swedish historical culture was evident in many of the narratives presented by the respondents. To perceive and approach Russia/the USSR as a problem seemed to be a given, and even though some of the teachers reflected on their own perspective, the bipolarity of the Cold War was not discussed or problematized in any of the interviews. In dealing with the Cold War as part of their own experience as individuals living during the time of the Cold War, the teachers saw the bipolarity of the world as part of that reality. An implicit teaching tool seemed embedded in their own experience of their narrated life. At the same time, this way of making sense of the world also contains a certain way of understanding - not only the world, devoid of ourselves - but also a specific way of understanding our own lives and memories, as well as a specific way of narrating those memories. This points to the importance of understanding how teaching tools in history teaching introduce ways of approximating the world.

There are extensive similarities between the socially sanctioned narrative of the Cold War - the mainstream historical culture or the official knowledge in Sweden - and the teachers' narratives of their own lives within that timeframe. Even though a few of them also went to Eastern Europe during or immediately after the Cold War their memories of the trips seem strongly affected by "what they already knew." In a few instances there were even vivid images from mass culture, school, or other parts of official knowledge, intervening with their personal memories, showing this entanglement of historical culture, social memory, and individual memory. The teachers clearly situate their personal memories in a cultural context and within a history which they - and the people they communicate with - know and accept as true. When talking about using their own (culturally entangled) memories as a tool in their history teaching, they give the impression of corroborating the historical culture around them, not acknowledging that these memories are also contingent upon that historical culture.

The teachers did not spontaneously indicate an approach to history akin to a historiographic gaze, and did not express any distinct notions of historical cultural self-awareness. In a very small glimpse during the total time of more than eight hours of interviews (for all interviews), one of the respondents actually recognized that his own personal memory was influenced by the cultural contingency of contemporary times, and filtered through social memory and official knowledge, when he discussed the former Prime Minister of Sweden, Olof Palme. He could for a moment express the insight that his perception was caught up in the web of culture built up around him, and that linked him to a specific perspective, ruled by his part in a larger historical culture. Even though it was only a glimpse, perhaps that kind of insight could help foster an awareness of the need for a historiographic gaze. An interesting aspect of this glimpse of self-awareness, however, is that the teacher himself did not recognize it as an important insight. 
This shows that even though some teachers obviously have the ability to recognize their situatedness in a historical culture, they probably do not see it as an important awareness that should be nurtured. This conclusion is also supported by earlier research indicating that history teachers and prospective history teachers have a hard time discussing matters of history's workings, probably because they lack the vocabulary to do so, something that might be missing from their teacher training (see e.g. McCrum, 2013; VanSledright \& Reddy, 2014).

An awareness of the influence of historical culture on their personal conception of history is probably essential for history teachers, and the indicated lack of such an awareness in these interviews could in that sense be seen as problematic for history teaching. Especially when narrating contemporary history of which the teacher has personal - and highly collectivized - memories, a historiographic gaze could be a powerful teaching tool, in order to show students the inherent cultural contingency of history. Because after all, it is important to convey to students that - as M3 puts it: "The Cold War was something that really shaped us, it shaped our whole society". But it is equally important to convey the fact that we also shape history by remembering some things (and forgetting others), and remembering them in a certain cultural context instilled with hindsight. If teachers cannot see themselves as situated in a historical culture, it can be very difficult to introduce a historiographic gaze and an understanding of the group-making characteristics of social memory, history and narrative to students. This could mean that the culturally dominant perspective on the Cold War, or any other historical event, will be reproduced by teachers (Thorp, 2019).

Our findings seem to indicate that there is a need for more research regarding how teachers practice history teaching (see e.g. Mårdh, 2019), both in relation to the teachers' view of their own embeddedness in historical culture, and also in relation to how they understand the subject's epistemological and ontological nature. Our method of not explicitly asking the teachers about disciplinary or cultural aspects of history was a prerequisite to give us a clue into what importance teachers tend to give these matters. Our study can however, because of the method we have employed, only say that there might be such a problem. In order to say something about to what extent this may be a problem, further research is needed. As indicated here, this future research needs to focus on teachers' ability to take their own situatedness into account, and their ideas of how history works, before we can say anything about what students may learn. 


\section{About the authors}

Henrik Åström Elmersjö is Associate Professor of history and education. His research focuses on historical culture, history education, and educational history. Institutional affiliation: Department of Historical, Philosophical and Religious Studies, Umeå University, 90187 Umeå

E-mail: henrik.astrom.elmersjo@umu.se

Robert Thorp is Senior Lecturer of history education. His research focuses on theoretical and cultural aspects of history education.

Institutional affiliation: Department of Education, Uppsala University, SE-750 02 Uppsala

E-mail: robert.thorp@edu.uu.se

\section{References}

Apple, M. (1993). Official knowledge: Democratic education in a conservative age. New York: Routledge.

Aronsson, P. (2004). Historiebruk: att använda det förflutna. Lund: Studentlitteratur.

Assman, J. (1992). Das kulturelle Gedächtnis: Schrift, Erinnerung und politische Identität in frühen Hochkulturen. München: Beck.

Becker, A. (2005). Memory gaps: Maurice Halbwachs, memory and the Great War. Journal of European Studies 35(1), 102-113. doi: https://doi.org/10.1177/0047244105051153

Clark, A. (2016). Private lives, public history. Melbourne: Melbourne University Press.

Climo, J.J. \& Cattell M.G., (Eds.). (2002). Social Memory and History: Anthropological Perspectives. New York: Altamira Press.

Conrad, M. et al. (2013). Canadians and their pasts. Toronto: University of Toronto Press.

Cubitt, G. (2007). History and memory. Manchester: Manchester University Press.

Dalsjö, R. (2006). Life-line lost: The rise and fall of 'neutral' Sweden's secret reserve option of wartime help from the West. Stockholm: Santérus.

Elmersjö, H.Å. (2011). The meaning and use of 'Europe' in Swedish history textbooks, 19102008. Education Inquiry, 2(1), 61-78. doi: https://doi.org/10.3402/edui.v2i1.21962

Elmersjö, H.Å. (2015). Historical culture and peace education: Some issues for history teaching as a means of conflict resolution. In R. Reynolds et al. (Eds.), Contesting and constructing international perspectives in global education (pp. 161-172). Rotterdam: Sense Publishers.

Elmersjö, H.Å. (2016). Negotiating the nation in history: The Swedish state approval scheme for textbooks and teaching aids from 1945 to 1983. Journal of Educational Media, Memory, and Society, 8(2), 16-35. doi: https://doi.org/10.3167/jemms.2016.080202

Feindt, G., Krawatzek, F., Mehler, D., Pestel, F. \& Trimçev, R. (2014). Entangled memory: Toward a third wave in memory studies. History and Theory, 53(1), 24-44. doi: https://doi.org/10.1111/hith.10693

Furrer, M. \& Gautschi P. (Eds.). (2016). Remembering and recounting the Cold War: Commonly shared history? Schwalbach: Wochenshau Verlag.

Halbwachs, M. (1992). On Collective Memory, (L.A. Coser, Ed. and Trans.). Chicago: University of Chicago Press. 
Hartog, F. (2015). Regimes of historicity: Presentism and experiences of time, (S. Brown, Trans.). New York: Columbia University Press.

Hirst, W., Phelps, E.A., Meksin, R., Vaidya, C.J., Johnson, M.K., Mitchell, K.J., ... Olsson, A. (2015). A ten-year follow-up of a study of memory for the attack of September 11, 2001: Flashbulb memories and memories for flashbulb events. Journal of Experimental Psychology: General, 144(3), 604-623. doi: http://dx.doi.org/10.1037/xge0000055

Holmén, J. (2006). Den politiska läroboken: Bilden av USA och Sovjetunionen i norska, svenska och finländska läroböcker under kalla kriget. Uppsala: Uppsala University.

Kansteiner, W. (2002). Finding meaning in memory: A Methodological critique of collective memory studies. History and Theory 41(2), 179-197. doi: https://doi.org/10.1111/00182656.00198

Karlsson. K-G. (2014). Historia, historiedidaktik och historiekultur - teori och perspektiv. In Karlsson, K-G. \& Zander, U. (Eds.), Historien är närvarande: historiedidaktik som teori och tillämpning (pp. 13-89). Lund: Studentlitteratur.

Lévesque, S. (2008). Thinking historically: Educating students for the $21^{\text {st }}$ century. Toronto: Buffalo.

Linde, C. (1993). Life stories: The creation of coherence. Oxford: Oxford University Press.

Linde, C. (2000). The acquisition of a speaker by a story: How history becomes memory and identity. Ethos 28(4), 608-632. doi: https://doi.org/10.1525/eth.2000.28.4.60

Mårdh, A. (2019). Between stability and contingency: A case study of the social, political and fantasmatic logics of Swedish history classroom practice. Nordidactica: Journal of Humanities and Social Science Education, 9(1), 132-155. doi: urn:nbn:se:kau:diva-71705

McCrum, E. (2013). History teachers' thinking about the nature of their subject. Teaching and Teacher Education, 35, 73-80. doi: https://doi.org/10.1016/j.tate.2013.05.004

Pakier, M. \& B. Stråth, B. (2010). Introduction: A European memory?” In M. Pakier \& B. Stråth (Eds.), A European memory: Contested histories and politics of rememberance (pp. 1-20). New York: Berghahn Books.

Parkes, R. (2011). Interrupting history: Rethinking history curriculum after "The end of history." New York: Peter Lang.

Persson, A. (2017). Lärartillvaro och historieundervisning: innebörder av ett nytt uppdrag i de mätbara resultatens tid. Umeå: Umeå University.

Persson, A. (2019). Americans and Russians as representatives of 'Us' and 'Them':

Contemporary Swedish school history textbooks and their portrayals of the central characters of the Cold War. In B. Christophe, P. Gautschi \& R. Thorp (Eds.), The Cold War in the Classroom: International Perspectives on Textbooks and Memory Practices (pp. 107-136). London: Palgrave Macmillan.

Persson, A. \& Thorp, R. (2017). Historieundervisningens existentialiserande potential. Nordidactica: Journal of Humanities and Social Science Education, 7(2), 59-74. doi: urn:nbn:se:kau:diva-48531

Pohrib, C. A. (2016). Writing childhoods, righting memory: Intergenerational remembrance in post-communist Romania. Journal of Educational Media, Memory, and Society, 8(2), 107-127. doi: https://doi.org/10.3167/jemms.2016.080206

Porat, D. (2004). It's not written here, but this is what happened: Students' cultural comprehension of textbook narratives on the Israeli-Arab conflict. American Educational Research Journal, 41(4), 963-996. doi: https://doi.org/10.3102/00028312041004963

Rosenzweig, R. \& Thelen, D. (1998). The presence of the past: Popular uses of history in American life. New York: Columbia University Press.

Rüsen, J. (2002). Geschichte im kulturprocess. Köln: Böhlau Verlag. 
Rüsen, J. (2007). Memory, history and the quest for the future. In L. Cajani \& A. Ross (Eds.), History teaching, identities, citizenship (European Issues in Children's Identity and Citizenship 7, pp. 13-34). London: Trentham.

Rüsen, J. (2012). Tradition: A principle of historical sense-generation and its logic and effect in historical culture. History and Theory, 51(4), 45-59. doi: https://doi.org/10.1111/j.1468-2303.2012.00646.x

Schrager, S. (1983). What is social in oral history? International Journal of Oral History, 4(2), 76-98.

Seixas, P. (2018). Education - between history and memory. In T. Epstein \& C. L. Peck (Eds.), Teaching and learning difficult histories in international contexts: A critical sociocultural approach (pp. 72-77). New York: Routledge.

Sjöberg, E. (2011). Battlefields of memory: The Macedonian conflict and Greek historical culture. Umeå: Umeå University.

Skolverket. (2011). Kursplan - Historia för grundskolan. Stockholm: Skolverket.

Thorp, R. (2015). Representation and interpretation: Textbooks, teachers, and historical culture.” IARTEM e-Journal, 7(2), 73-99.

Thorp, R. (2016). Uses of history in history education. Umeå: Umeå University.

Thorp, R. (2017). Experiencing, using, and teaching history: Two teachers’ relations to history and educational media. Journal of Educational Media, Memory, and Society, 9(2), 129-146. doi: https://doi.org/10.3167/jemms.2017.090207

Thorp, R. (2019). Pedagogical entanglements and the Cold War: A comparative study of the opening lessons on the Cold War in Sweden and Switzerland. In B. Christophe, P. Gautschi \& R. Thorp (Eds.), The Cold War in the Classroom: International Perspectives on Textbooks and Memory Practices (pp. 423-448). London: Palgrave Macmillan.

Van Sledright, B \& Reddy, K. (2014). Changing epistemic beliefs? An esporatory study of cognition among prospective history teachers. Temp \& Argumento, 6(11), 28-68. doi: http://dx.doi.org/10.5965/2175180306112014

Wineburg S., Mosborg, S., Porat, D. \& Duncan, A. (2007). Common belief and the cultural curriculum: An intergenerational study of historical consciousness. American Educational Research Journal 44(1), 40-76.doi: https://doi.org/10.3102/0002831206298677

Zanazanian, P. (2009). Historical Consciousness and the Construction of Inter-Group Relations: The Case of Francophone and Anglophone History School Teachers in Quebec. Montréal: Université de Montréal.

Zanazanian, P. \& Moisan, S. (2012). Harmonizing two of history teaching's main social functions: Franco-Québécois history teachers and their predispositions to catering to narrative diversity. Education Sciences, 2(2), 255-275. doi: https://doi.org/10.3390/educsci2040255

Zeltner, J. (2010). When the centre fell apart: The treatment of September 11 in selected anglophone narratives. Frankfurt: Peter Lang. 